\title{
Transitions in European land-management regimes between 1800 and 2010
}

Martin Rudbeck Jepsen,Tobias Kuemmerle, Daniel Müller, Karlheinz Erb, Peter H. Verburg, Helmut Haberl, Jens Peter Vesterager, Maja Andrič, Marc Antrop, Gunnar Austrheim,Ismo Björn, Alberte Bondeau, Matthias Bürgi, Jessica Bryson, Gilles Caspar, Louis F. Cassar, Elisabeth Conrad, Pavel Chromý, Vidmantas Daugirdas, Veerle Van Eetvelde, Ramon Elena-Rosselló,Urs Gimmi, Zita Izakovicova, Vít Jančák, Ulf Jansson, Drago Kladnik, Jacek Kozak, Eva Konkoly-Gyuró, Fridolin Krausmann, Ülo Mander, John McDonagh, Jaan Pärn, Maria Niedertscheider, Olgerts Nikodemus, Katarzyna Ostapowicz, Marta Pérez-Soba, Teresa Pinto-Correia, Gintaras Ribokas, Mark Rounsevell, Despoina Schistou, Claude Schmit, , Theano S. Terkenli, Aud M. Tretvik, Piotr Trzepacz, Angheluta Vadineanu, Ariane Walz, Edvin Zhllima, Anette Reenberg.

\begin{abstract}
Land use is a cornerstone of human civilization, but also intrinsically linked to many global sustainability challenges-from climate change to food security to the ongoing biodiversity crisis. Understanding the underlying technological, institutional and economic drivers of land-use change, and how they play out in different environmental, socio-economic and cultural contexts, is therefore important for identifying effective policies to successfully address these challenges. In this regard, much can be learned from studying long-term land-use change. We examined the evolution of European land management over the past 200 years with the aim of identifying (1) key episodes of changes in land management, and (2) their underlying technological, institutional and economic drivers. To do so, we generated narratives elaborating on the drivers of land use-change at the country level for 28 countries in Europe. We qualitatively grouped drivers into land-management regimes, and compared changes in management regimes across Europe. Our results allowed discerning seven land-management regimes, and highlighted marked heterogeneity regarding the types of management regimes occurring in a particular country, the timing and prevalence of regimes, and the conditions that result in observed bifurcations. However, we also found strong similarities across countries in the timing of certain landmanagement regime shifts, often in relation to institutional reforms (e.g., changes in EU agrarian policies or the emergence and collapse of the Soviet land management paradigm) or to technological innovations (e.g., drainage pipes, tillage and harvesting machinery, motorization, and synthetic fertilizers). Land reforms frequently triggered changes in land management, and the location and timing of reforms had substantial impacts on land-use outcomes. Finally, forest protection policies and voluntary cooperatives were important drivers of land-management changes. Overall, our results demonstrate that land-system changes should not be conceived as unidirectional developments following predefined trajectories, but rather as path-dependent processes that may be affected by various drivers, including sudden events.
\end{abstract}

Keywords Land-use change; Long-term socio-ecological research; Land-management regimes; Institutional change; Technological innovation; Policy; Path dependency

doi: $\underline{10.1016 / j . l a n d u s e p o l .2015 .07 .003}$

Citação: Jepsen, M.R., et al, 2015, Transitions in European land-management regimes between 1800 and 2010. Land Use Policy Volume 49, December 2015, Pages 53-64 doi:10.1016/j.landusepol.2015.07.003 